\title{
Understanding the odour network
}

\author{
Ritesh Kumar ${ }^{1,2^{*}}$, Rishemjit Kaur ${ }^{1,2}$, Amol P Bhondekar ${ }^{1,2}$, Pawan Kapur ${ }^{1,2}$ \\ From 1st International Workshop on Odor Spaces \\ Hannover, Germany. 4-7 September 2013
}

We live in a sea of data which we interact, inadvertently or advertently, through our senses. Among major sensory modalities, the physical stimulus attributes to perception mapping is more or less well defined in vision and audition, but not in olfaction. Although, the molecular concentration to perceived odor intensity mapping has been established [1], there is no known general systematic relationship of molecular properties onto the olfactory percept. In other words, it has been a challenge to predict the smell of a novel molecule by its physicochemical structure, or the physicochemical structure of a novel smell. There has been a large progress in this decade towards understanding the molecular and neural basis of olfactory perception [2], [3], [4], [5], [6], [7]. Khan et. al predicted the odor pleasantness based on odorant structure and they considered odorant database of 144 odorants [8]. Kermen et. al [9] reported the relationship between olfactory note and molecular structure recently. The knowledge of chemistry, odor scientists and efforts of IBM [10] has given us huge database of almost 31 million molecules along with their physical, structural and other properties. This dataset is not structured in terms of odor, and no attempt has been made to understand and organize this huge data in olfaction space. One of the most important aspects of understanding the data is visualization. Recently, network analysis has grabbed much attention due to its clear representation in terms of entities and relationship and more often than not, they provide some really interesting insights into the data they represent [11]. The present work aims at discovering inherent statistical structure in large chemical and perceptual databases available online in order to derive principles for predicting odor perception from the chemical structure of odorants via network analysis of Flavournet dataset. The Flavournet dataset consists of 738 odorants arranged by chromatographic and sensory properties. An adjacency

\footnotetext{
${ }^{1}$ CSIR- Central Scientific Instruments Organisation, Chandigarh, India

Full list of author information is available at the end of the article
}

list of odorants on the basis of perceived smell was created. Further, an odor network was created in which each odorant forms the node and weight of edge between them shows the number of odors they share with each other. The initial results give very good insights about the dataset such as there are two islands in this network. The fully connected smaller island is only inhabited by alkane family of odors and the bigger island follows the degree distribution of a scale free network. Further, the physical and structural descriptors were superimposed on this graph in order to understand it in a better way. The results provide useful insights into the odor space.

\section{Authors' details}

${ }^{1}$ CSIR- Central Scientific Instruments Organisation, Chandigarh, India.

${ }^{2}$ Academy of Scientific and Innovative Research, New Delhi, India.

\section{Published: 16 April 2014}

\section{References}

1. Cain W: Odor intensity: Differences in the exponent of the psychophysical function. Percept Psychophys 1969, 6:349-354.

2. Lavine BK, White C, Mirjankar N, Sundling CM, Breneman CM: Odorstructure relationship studies of tetralin and indan musks. Chem Senses 2012, 37:723-36.

3. Zarzo M: Hedonic judgments of chemical compounds are correlated with molecular size. Sensors (Basel) 2011, 11:3667-86.

4. Hasegawa T, Izumi H, Tajima Y, Yamada H: Structure-odor relationships of a-santalol derivatives with modified side chains. Molecules 2012, 17:2259-70.

5. Czerny M, Brueckner R, Kirchhoff E, Schmitt R, Buettner A: The Influence of Molecular Structure on Odor Qualities and Odor Detection Thresholds of Volatile Alkylated Phenols. Chem Senses 2011, 539-553.

6. Schmuker M, de Bruyne M, Hähnel M, Schneider G: Predicting olfactory receptor neuron responses from odorant structure. Chem Cent J 2007, 1:11.

7. Schmuker M, Schneider G: Processing and classification of chemical data inspired by insect olfaction. Proc Natl Acad Sci 2007, 104:20285-20289.

8. Khan RM, Luk C-H, Flinker A, Aggarwal A, Lapid H, Haddad R, Sobel N: Predicting odor pleasantness from odorant structure: pleasantness as a reflection of the physical world. J Neurosci 2007, 27:10015-23.

9. Kermen F, Chakirian A, Sezille C, Joussain P, Le Goff G, Ziessel A, Chastrette M, Mandairon N, Didier A, Rouby C, Bensafi M: Molecular complexity determines the number of olfactory notes and the pleasantness of smells. Sci Rep 2011, 1:206. 
10. IBM News room: IBM Contributes Data to the National Institutes of Health to Speed Drug Discovery and Cancer Research Innovation United States. IBM news 2011.

11. Ahn Y-Y, Ahnert SE, Bagrow JP, Barabási A-L: Flavor network and the principles of food pairing. Sci Rep 2011, 1:196.

doi:10.1186/2044-7248-3-S1-P7

Cite this article as: Kumar et al:. Understanding the odour network. Flavour 2014 3(Suppl 1):P7.

Submit your next manuscript to BioMed Central and take full advantage of:

- Convenient online submission

- Thorough peer review

- No space constraints or color figure charges

- Immediate publication on acceptance

- Inclusion in PubMed, CAS, Scopus and Google Scholar

- Research which is freely available for redistribution

Submit your manuscript at www.biomedcentral.com/submit
() Biomed Central 